\title{
Cytotoxic Effects of Diclofenac and Ibuprofen Zinc (II)- Nicotinamide Ternary Complexes in Breast Cancer Cell Lines
}

Emanuelle Fraga da Silva ${ }^{1}$

https://orcid.org/0000-0002-8624-7164

Paulo Roberto dos Santos ${ }^{2}$

https://orcid.org/0000-0002-5777-9073

Krist Helen Antunes Fernandes ${ }^{1}$

https://orcid.org/0000-0002-1525-6581

Deise do Nascimento de Freitas ${ }^{1}$

https://orcid.org/0000-0001-6210-8285
Rafael Fernandes Zanin ${ }^{3}$

https://orcid.org/0000-0003-3146-0221

\author{
Pablo Machado 4 \\ https://orcid.org/0000-0001-5616-9583 \\ Sidnei Moura² \\ https://orcid.org/0000-0003-1903-6735
}

Ana Paula Duarte de Souza ${ }^{\star}$
https://orcid.org/0000-0002-6021-5068

${ }^{1}$ Pontifical Catholic University of Rio Grande do Sul (PUCRS), Laboratory of Clinical and Experimental Immunology, School of Health Science, Porto Alegre, Rio Grande do Sul, Brazil; ${ }^{2}$ University of Caxias do Sul, Laboratory of Natural and Synthetics Products, Caxias do Sul, Rio Grande do Sul, Brazil; ${ }^{2}$ La Salle University, Department of Health and Human Development, Canoas, RS, Brazil; ${ }^{4}$ Pontifical Catholic University of Rio Grande do Sul (PUCRS), Research Center in Molecular and Functional Biology, National Institute of Science and Technology in Tuberculosis, Porto Alegre, Rio Grande do Sul, Brazil.

Editor-in-Chief: Alexandre Rasi Aoki

Associate Editor: Daniel Fernandes

Received: 2021.01.12; Accepted: 2021.05.09.

*Correspondence: ana.duarte@pucrs.br; Tel.: +55 33203500 ext. 3931 (A.P.D.S.).

\section{HIGHLIGHTS}

- Diclofenac and ibuprofen-derived complexes decrease viability of breast cancer cell lines

- Complex 1 presented antitumor effect in all breast cancer cell lines tested including on triple negative cell line (MDA-MB-231) (IC50 202 $\mu \mathrm{M})$

- Complex 1 was selective for both 4T1 and MDA-MB-231 cells

Abstract: Breast cancer is one of the leading types of cancer worldwide, and the search for new treatment options are crucial. Nonsteroidal anti-inflammatory drugs (NSAIDs) - specially ibuprofen and diclofenac-, have shown antitumoral effect against several types of cancer. The synthesis of organometallic compounds has shown significant improvements in pharmacological properties and efficacy of organic molecules. Two zinc II ternary complexes containing the NSAIDs diclofenac and ibuprofen and nicotinamide neutral linker (Nic) were obtained by the two-step solvent metalligand complexation method. The compounds $\mathrm{Zn}_{2}$ (Diclof) $)_{4}(\mathrm{Nic})_{2}$ (complex 1) and $\mathrm{Zn}_{2}(\mathrm{lbup})_{4}(\mathrm{Nic})_{2}$ (complex 2) were tested in breast cancer cell lines (4T1, MCF-7 and MDA-MB-231) to evaluate their cytotoxicity, comparing to ibuprofen and diclofenac as controls. We found that both complex 1 and 2 exerted more than $60 \%$ reduction in $4 \mathrm{~T} 1$ viability at $250 \mu \mathrm{M}$, and complex 
2 decreased cell viability at $250 \mu \mathrm{M}$ and $137.5 \mu \mathrm{M}$ in MCF-7 (34.35\% and $26.42 \%$ reduction, respectively) and in MDA-MB-231 (57.2\% and 22.88\% reduction, respectively), all compared to controls. Complex 1 was selective only in MCF-7, and complex 2 was selective in both MCF-7 and MDA-MB-231. In summary, our data showed that the cytotoxic effect of complex $\mathbf{1}$ and $\mathbf{2}$ is increased comparing to their original NSAID in different breast cancer cell lines, highlighting their potential anti-tumoral activity.

Keywords: NSAIDs; Zinc complexes; cytotoxicity; coordination compounds; cell viability.

\section{INTRODUCTION}

Cancer is the second most cause of death worldwide, with 9.6 million deaths estimated in 2018. (1) According to Global Cancer Statistics 2018 (2), for females, breast cancer is the leading type of cancer, with $24.2 \%$ of incidence, and leading cause of cancer death, with $15.0 \%$ mortality rate. Breast cancer involves an inherited component, with multiple susceptibility genes linked to it, and has a wide variation in tumor morphology and clinical response. Like all cancer types, it implicates in high costs treatments, with several side effects, therefore the search for more specific and efficient compounds against breast cancer is crucial. (2)

Nonsteroidal anti-inflammatory drugs (NSAIDs) are a class of molecules that act on inflammation, vasodilatation, vasoconstriction, and as analgesics and antipyretics. Their mechanism of action is based on the inhibition of COX and LOX enzymes, which are involved in the biosynthesis of prostaglandins (PGs) $(3,4)$. Arachidonic acid (AA) is converted by COX and LOX enzymes into lipid mediators known as eicosanoids, which include prostaglandins, thromboxanes, leukotrienes, lipoxins, resolvins, and eoxins, and are involved in inflammation and cancer (5-7). There have been several studies showing an inverse correlation between the use of NSAIDs and the incidence of several types of cancer, such as breast $(8,9)$, lung $(10,11)$, prostate (12), bladder (13), ovary (14,15), esophagus (16) and stomach (17). These correlations have prompted studies on antitumoral effects of NSAIDs. (18)

Chronic inflammation can lead to the initiation of cancer (19-21), and COX enzymes (specially COX-2 (22)) are overexpressed in many malignant lesions (23), such as colon (24), stomach (25) and breast cancer (26). This enzyme is also involved in cancer development (27), poorer patient prognosis (28) and tumor invasion (29). Thus, NSAIDs like ibuprofen and diclofenac can have an antitumoral effect on cancer, as they inhibit both COX-1 and COX-2 enzymes (30).

Organometallic complexes are formed when a metal coordinates with organic compounds, being considered as an intermediate form between organic and inorganic derivatives. Studies have shown that these complexes can be potential anticancer drugs (31-35), since they exhibit a greater effect than the original organic molecule, and higher kinetic stability, structural diversity, ability to bind biological targets, variable oxidation states and the possibility of rational ligand design to control kinetic properties $(36,37)$. Metallodrugs formed using ibuprofen and diclofenac as chelating agents have shown anticancer activity against cancer cell lines (38-41). Studies using metallodrugs containing ibuprofen showed antiproliferative activity in vitro, and compounds using both diclofenac and ibuprofen also led to inhibition of COX and LOX enzymes $(38,39)$.

Based on these studies, our group sought to examine the effect of two organometallic compounds, complex 1 and complex 2, synthesized and previously described by Moura 2020 (42). The compounds were synthesized using ibuprofen and diclofenac, forming ternary complexes of Zn-Diclof and Zn-lbup with nicotinamide (Nic) as a nitrogen ligand. Complexes $\mathbf{1}$ and $\mathbf{2}$ were tested against three breast cancer (BC) cell lines: MCF-7, a human invasive breast ductal carcinoma, $\mathrm{ER}^{+}, \mathrm{PR}^{+-}$, HER2- luminal and often chemotherapy responsive; MDA-MB-231, also human invasive breast ductal carcinoma, triple negative, claudin-low and intermediate responsive to chemotherapy; and 4T1, a mouse mammary gland that mimics an animal stage IV human breast cancer $(43,44)$. We aimed to observe the effect of complexes 1 and 2 in inhibiting proliferation of breast cancer cell lines.

\section{MATERIAL AND METHODS}

Zinc nitrate, zinc sulphate, nicotinamide, sodium carbonate and ethanol $99 \%$ were purchased from Sigma-Aldrich (St. Louis, Missouri, USA). Potassium diclofenac 99\% and ibuprofen 99\% (pharmaceutical grade) were obtained from Sigma-Aldrich. Ultrapure water was obtained from the Milli-Q (Millipore) apparatus. Ethanol and dimethylformamide (DMF) were purchased form Sigma-Aldrich (grade reagent) and used without further purification. 


\section{Physical measurements}

$1 \mathrm{H}$ and $13 \mathrm{C}$ NMR analysis was performed on a Fourier 300 spectrometer (Bruker) $(300.18 \mathrm{MHz}$ from $1 \mathrm{H}$ and $75.49 \mathrm{MHz}$ from $13 \mathrm{C}$ with $5 \mathrm{~mm}$ probe) with 32 scans for $1 \mathrm{H}$ and 5000 scans for $13 \mathrm{C}$, using $\mathrm{CDCl} 3$ and DMSO-D6 as solvents. Infrared analysis was performed on a Perkin Elmer Spectrum 400 FTIR spectrometer using solid samples by the $\mathrm{KBr}$ pellet technique. Spectral data were obtained in the spectral interval from 400 to $4000 \mathrm{~cm}-1$ (wavenumber) with a resolution of $1.0 \mathrm{~cm}-1$ for 32 scans. High resolution mass spectroscopy was performed according to the following conditions: complex solutions $(1.0 \mu \mathrm{g} \cdot \mathrm{mL}-1 \mathrm{H} 2 \mathrm{O}: \mathrm{MeOH} 1: 1 \mathrm{v} / \mathrm{v})$ were individually infused directly into the ESI source by means of a syringe pump (Harvard Apparatus) at a flow rate of $150 \mu \mathrm{L}$.min-1. ESI (+)-MS and tandem ESI (+)-MS/MS were acquired using a hybrid highresolution and high accuracy $(5 \mu \mathrm{L}$.min-1) MicroTof (Q-TOF) mass spectrometer (Bruker Scientific) under the following conditions: capillary and cone voltages were set to $+3500 \mathrm{~V}$ and $+40 \mathrm{~V}$, respectively, with a desolvation temperature of $100{ }^{\circ} \mathrm{C}$. For ESI (+)-MS/MS, the energy for the collision-induced dissociations (CIDs) was optimized for each component. For data acquisition and processing in Q-TOF, control data analysis software (Bruker Scientific) was used. The data were collected in the $\mathrm{m} / \mathrm{z}$ range of 100-2000 at the speed of two scans/s, providing the resolution of 10,000 (FWHM) at m/z 200 .

\section{Chemical synthesis}

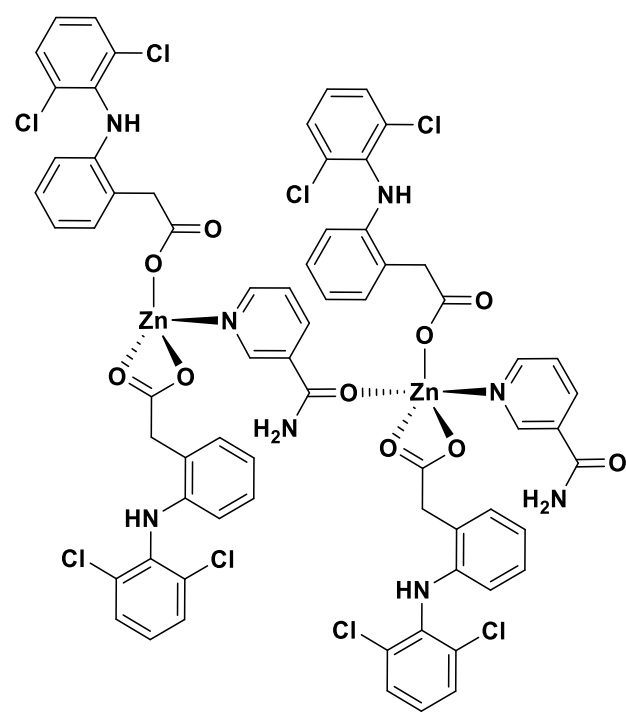

1

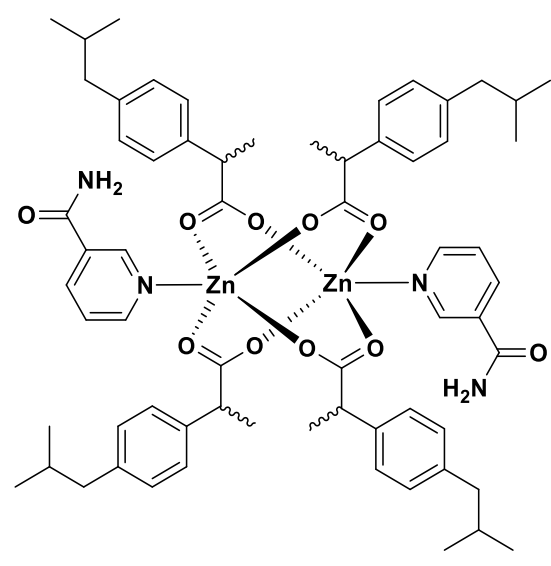

2

Figure 1. Ternary complexes 1 and 2.

Complexes 1 and 2 were prepared and analyzed according to Dos Santos and coauthors (42). For complex $1,0.655 \mathrm{~g}(1.0 \mathrm{mmol})$ of zinc diclofenac salt previously obtained according to Abu Ali and coauthors (45)was dissolved in $20 \mathrm{~mL}$ of ethanol $99 \%$ at room temperature and vigorous stir. An ethanolic solution of nicotinamide $(0.244 \mathrm{~g}, 2.0 \mathrm{mmol})$ was then added dropwise over first solution and keep stirring for two $\mathrm{h}$. The white powder was obtained after one week by filtration and vacuum drier. Yield: $0.70 \mathrm{~g},(90 \%)$; MP: $180^{\circ} \mathrm{C}$; IR (cm-1, KBr pellet): 3310, 3183, 3095, 3072, 3039, 2969, 2925, 1679, 1622, 1607, 1592, 1576, 1564 (va COO-), 1506, 1415 (vs COO-), 1351, 1303, 1283, 1249, 1199, 1164, 1094, 1058, 869, 837, 774, 747, 720, 698, 656; ( $\Delta$ v COO-) 149; 1HNMR ( $\delta$-ppm, DMSO-D6): 3.59 (s-4H, 2CH2), $6.28(\mathrm{~d}-2 \mathrm{H}, 2 \mathrm{CH}, \mathrm{JH}-\mathrm{H}=9 \mathrm{~Hz})$, $6.82(\mathrm{dt}-2 \mathrm{H}, 2 \mathrm{CH}, \mathrm{JH}-\mathrm{H}=7 \mathrm{~Hz}), 7.01(\mathrm{dt}-2 \mathrm{H}, 2 \mathrm{CH}, \mathrm{JH}-\mathrm{H}=7 \mathrm{~Hz}), 7.08$ (dd-2H, 2CH, JH-H = 8Hz), 7.15 (dd$2 \mathrm{H}, 2 \mathrm{CH}, \mathrm{JH}-\mathrm{H}=7 \mathrm{~Hz}), 7.42(\mathrm{~d}-4 \mathrm{H}, 4 \mathrm{CH}, \mathrm{JH}-\mathrm{H}=8 \mathrm{~Hz}), 7.48(\mathrm{~m}-1 \mathrm{H}, \mathrm{CH}(\mathrm{Nic}), \mathrm{JH}-\mathrm{H}=5 \mathrm{~Hz}), 7.63(\mathrm{~s}-1 \mathrm{H}$, $\mathrm{NH}(\mathrm{Nic})), 8.19(\mathrm{~s}-1 \mathrm{H}, \mathrm{NH}(\mathrm{Nic})), 8.21(\mathrm{~m}-1 \mathrm{H}, \mathrm{CH}, \mathrm{JH}-\mathrm{H}=8 \mathrm{~Hz}), 8.30$ (s-2H, 2NH(Diclof)), 8.69 (dd-1H, $\mathrm{CH}(\mathrm{Nic}), \mathrm{JH}-\mathrm{H}=5 \mathrm{~Hz}$ ), 9.03 (ds-1H(Nic), CH); 13CNMR ( $\delta$-ppm, DMSO-D6): $40.73(2 \mathrm{CH} 2), 116.34(2 \mathrm{CH})$, $120.82(2 \mathrm{CH}), 123.60(\mathrm{CH}(\mathrm{Nic})), 124.59(2 \mathrm{CH}), 126.56(2 \mathrm{CH}), 126.85(2 \mathrm{C}), 128.97(2 \mathrm{CH}), 129.12(4 \mathrm{CH})$, $129.82(\mathrm{CH}(\mathrm{Nic})), 130.61(2 \mathrm{C}), 135.46$ ( $\mathrm{CH}(\mathrm{Nic})), 137.57$ (2C), $142.86(4 \mathrm{CCl}), 148.75(\mathrm{CH}(\mathrm{Nic})), 151.92$ (CH(Nic)), 166.45 (CON(Nic)), 177.40 (2COO-(Diclof)); HRMS ESI (+) m/z 1253.9743 (C54H42Cl6N7O8Zn2) [M-diclof]+, 1131,9225 (C48H36Cl6N5O7Zn2) [M-diclof-nic]+, $1009.8843 \quad$ (C42H30Cl6N3O6Zn2) [Zn2(diclof)3]+, 796.9771 (C34H26Cl4N4NaO5Zn) [Zn(diclof)2Nic+Na]+, 774.9993 (C34H27Cl4N4O5Zn) [Zn(diclof)2Nic+H]+, $674.9318(\mathrm{C} 28 \mathrm{H} 20 \mathrm{Cl} 4 \mathrm{~N} 2 \mathrm{NaO} 4 \mathrm{Zn})$ [Zn(diclof)2+Na]+, $652.9525(\mathrm{C} 28 \mathrm{H} 21 \mathrm{Cl} 4 \mathrm{~N} 2 \mathrm{O} 4 \mathrm{Zn})$ [Zn(diclof)2+H]+, $602.0314 \quad(\mathrm{C} 26 \mathrm{H} 22 \mathrm{Cl} 2 \mathrm{~N} 5 \mathrm{O} 4 \mathrm{Zn}) \quad$ [Zn(diclof)(nic)2]+, 478.9849 (C20H16Cl2N3O3Zn) 
[Zn(diclof)(nic)]+, $398.9627(\mathrm{C} 14 \mathrm{H} 14 \mathrm{Cl} 2 \mathrm{~N} 2 \mathrm{NaO} 2 \mathrm{Zn})$ [Zn(diclof)+NH4+Na]+, 374.9478 (C14H12Cl2NO3Zn) $[\mathrm{Zn}$ (diclof)+H2O]+, $357.9379 \quad(\mathrm{C} 14 \mathrm{H} 10 \mathrm{Cl} 2 \mathrm{NO} 2 \mathrm{Zn}) \quad[\mathrm{Zn}$ (diclof) $]+, \quad 318.0053 \quad(\mathrm{C} 14 \mathrm{H} 11 \mathrm{Cl} 2 \mathrm{NNaO})$ [diclof+H+Na]+, $296.0233(\mathrm{C} 14 \mathrm{H} 12 \mathrm{Cl} 2 \mathrm{NO} 2)[$ diclof $+2 \mathrm{H}]+$.

For complex 2, $0.475 \mathrm{~g} \mathrm{(1.0} \mathrm{mmol)} \mathrm{of} \mathrm{zinc} \mathrm{ibuprofen} \mathrm{salt} \mathrm{previously} \mathrm{obtained} \mathrm{according} \mathrm{to} \mathrm{Abu} \mathrm{Ali} \mathrm{and}$ coauthors (46) was dissolved in $20 \mathrm{~mL}$ of dimethylformamide (DMF) at room temperature and vigorous stir. Nicotinamide $(0.244 \mathrm{~g}, 2.0 \mathrm{mmol})$ was then added dropwise over first solution and keep stirring for two $\mathrm{h}$. The clear solution was concentered by vacuum evaporation at $20 \%$ of start volume and keeped in dark flask at room temperature for 30 days. The clear crystals were then obtained by filtration, washed with cold DMF and dried over freeze drier by $24 \mathrm{~h}$. Yield: $0.42 \mathrm{~g}(70 \%)$; MP:148 ${ }^{\circ} \mathrm{C}$; IR $(\mathrm{cm}-1, \mathrm{KBr}$ pellet): 3440, 3318, 3283, 3201, 3182, 2959, 2930, 2867, 1689, 1636 (va COO-), 1604, 1575, 1512, 1458 (vs COO-), 1412, 1372, 1287, 1199, 1056, 793, 699, 601, ( $\Delta v$ COO-) 178; 1HNMR ( $\delta$-ppm, CDCl3): 0.82 (d-12H, 4CH3, JH-H = 6Hz), 1.35 $(\mathrm{d}-6 \mathrm{H}, 2 \mathrm{CH} 3, \mathrm{JH}-\mathrm{H}=7 \mathrm{~Hz}), 1.74(\mathrm{sep}-2 \mathrm{H}, 2 \mathrm{CH}, \mathrm{JH}-\mathrm{H}=7 \mathrm{~Hz}), 2.27(\mathrm{~d}-4 \mathrm{H}, 2 \mathrm{CH} 2, \mathrm{JH}-\mathrm{H}=7 \mathrm{~Hz}), 3.62(\mathrm{q}-2 \mathrm{H}$, $2 \mathrm{CH}, \mathrm{JH}-\mathrm{H}=7), 4,98(\mathrm{~s}-1 \mathrm{H}, 1 \mathrm{NH}(\mathrm{Nic})), 6.83(\mathrm{~d}-4 \mathrm{H}, 4 \mathrm{CH}, \mathrm{JH}-\mathrm{H}=8 \mathrm{~Hz}), 7,00(\mathrm{~d}-4 \mathrm{H}, 4 \mathrm{CH}, \mathrm{JH}-\mathrm{H}=8 \mathrm{~Hz}), 7.43$ (dd-1H, $1 \mathrm{CH}(\mathrm{Nic}), \mathrm{JH}-\mathrm{H}=8 \mathrm{~Hz}), 8,26(\mathrm{~s}-1 \mathrm{H}, 1 \mathrm{NH}(\mathrm{Nic})), 8.43(\mathrm{dt}-2 \mathrm{H}, 2 \mathrm{CH}(\mathrm{Nic}), \mathrm{JH}-\mathrm{H}=8 \mathrm{~Hz}), 8.59$ (dd-2H, $2 \mathrm{CH}(\mathrm{Nic}), \mathrm{JH}-\mathrm{H}=5 \mathrm{~Hz}$ ), 8.85 (ds-2H, 2CH(Nic), JH-H = 2Hz); 13CNMR ( $\delta$-ppm, CDCl3): 19.54 (2CH3), 22.33 (4CH3), $30.09(2 \mathrm{CH}), 44.86(2 \mathrm{CH}), 46.24(2 \mathrm{CH} 2), 124.57(\mathrm{CH}(\mathrm{Nic})), 127.09(4 \mathrm{CH}), 129.07(4 \mathrm{CH}), 130.70$ $(\mathrm{CH}(\mathrm{Nic})), 137.01$ (2C), 139.76 (CH(Nic)), 140.06 (2C), $146.83(\mathrm{CH}(\mathrm{Nic})), 150.26$ (C(Nic)), 164.39 (CON(Nic))183.07 (2CO2-); HRMS ESI (+): m/z 1093.3807 (C58H74N2NaO9Zn2) [M-Nic+Na]+, 1071.3983 (C58H75N2O9Zn2) [M-Nic+H]+, 987.3219 (C51H63N4O8Zn2) [M-ibup]+, 865.2731 (C45H57N2O7Zn2) [Zn2(ibup)3(Nic)]+, 883.2853 (C45H59N2O8Zn2) [Zn2(ibup)3(Nic)+H2O]+, 619.2110 (C32H40N2NaO5Zn) [Zn(ibup)2(Nic)+Na]+, 597.2296 (C32H41N2O5Zn) $\quad[\mathrm{Zn}($ ibup)2(Nic)+H]+, 513.1469 (C25H29N4O4Zn) $[\mathrm{Zn}$ (ibup)(Nic)2]+, $\quad 475.1813 \quad(\mathrm{C} 26 \mathrm{H} 35 \mathrm{O} 4 \mathrm{Zn}) \quad[\mathrm{Zn}$ (ibup)2+H]+, $328.0889 \quad(\mathrm{C} 13 \mathrm{H} 23 \mathrm{NNaO} Z \mathrm{Zn})$ [Zn(ibup)+H2O+NH4+Na]+, 287.0620 (C13H19O3Zn) $\quad[\mathrm{Zn}$ (ibup)+H2O $]+, \quad 229.1201 \quad(\mathrm{C} 13 \mathrm{H} 18 \mathrm{NaO} 2)$ $[$ ibup $+\mathrm{Na}+\mathrm{H}]+$.

\section{Chemical synthesis}

The compounds were synthesized according to Moura 2020 [42].

\section{Cell lines}

The cell lines MCF-7 (human mammary gland adenocarcinoma), 4T1 (Mus musculus mammary gland), MDA-MB-231 (human mammary gland adenocarcinoma) and Vero (Cercopithecus aethiops kidney normal) were purchased from the American Type Culture Collection (ATCC). MCF-7 cells were cultured in DMEM Low glucose, MDA-MB-231 and Vero in DMEM High glucose, and 4T1 in RPMI, all supplemented with 10\% Fetal bovine serum (FBS). All cells were incubated in a humidified incubator at $5 \% \mathrm{CO}_{2}$ and $37{ }^{\circ} \mathrm{C}$, and experiments were performed using freshly thawed cells after three passages. Cell lines were tested for Mycoplasma contamination.

\section{Cytotoxicity assay}

Cells were seeded in 96-well flat-bottom plates at concentrations of $5 \times 10^{3}$ cells/well for MCF-7, MDAMB-231 and 4T1 cells and $2 \times 10^{3}$ cells/well for Vero cells. After $24 \mathrm{~h}$ of incubation, $250 \mu \mathrm{M}, 137.5 \mu \mathrm{M}, 25 \mu \mathrm{M}$, $13.75 \mu \mathrm{M}$, or $2.5 \mu \mathrm{M}$ of complex 1 and complex 2 was added and the plates were incubated for an additional $24 \mathrm{~h}$ at $37^{\circ} \mathrm{C}$ in a humidified incubator with $5 \% \mathrm{CO} 2$. For the treatment curve, $4 \mathrm{~T} 1$ cells were incubated with $250 \mu \mathrm{M}$ of compounds and controls for $6 \mathrm{~h}, 12 \mathrm{~h}, 24 \mathrm{~h}$ and $48 \mathrm{~h}$. For the vehicle control, DMSO was added in the highest concentration that was used to dilute the compounds. As an additional negative control (NC), untreated cells were also assayed. Cell viability was assessed using a colorimetric assay based on the reduction of 3-[4,5-dimethylthiazol-2-y1]-2,-diphenyltetrazolium bromide (MTT) by mitochondrial enzymes (Molecular Probes ${ }^{\mathrm{TM}}$, Thermo Fisher Scientific, Waltham, MA, USA). Briefly, $100 \mu \mathrm{L}$ of medium was removed and $40 \mu \mathrm{L}$ of MTT reagent $(5-\mathrm{mg} / \mathrm{mL})$ was added into each well. Cells were incubated for $4 \mathrm{~h}$ and the precipitated formazan crystals were dissolved in dimethyl sulfoxide (DMSO). Finally, the optic density (OD) was analyzed at 570/620 nm using a micro-plate reader (EZ Read 400, Biochrom). Assays were performed in triplicate. For cytotoxicity calculation, the OD of the treated cells was multiplied by the percentage equivalent to the cells treated with DMSO, and then divided by the OD of the cells treated with DMSO, as the following: 
OD of $\mathrm{NC}-100 \%$

OD of DMSO treated cells $-\mathrm{x}$

Viability $=(\mathrm{OD}$ of treated cells $x \%$ equivalent to DMSO) / (OD of DMSO treated cells)

\section{Data analysis}

The half maximal inhibitory concentrations (IC50) of compounds and controls were calculated using linear and polynomial regression analyses using Microsoft Excel 2009, with consequent resolution of the line equation of the graph with Wolfram Alpha. The IC50 values were reported as a mean of two independent experiments. The selectivity index (SI) was calculated according to the following equation:

$\mathrm{SI}=$ (IC50 of Vero cells) / (IC50 of tumor cells)

where a $\mathrm{SI}>1$ indicates that the compound is more cytotoxic to tumor cell, and a $\mathrm{SI}<1$ indicates the opposite $(45,46)$.

Statistical analyses were performed with GraphPad Prism 5 (GraphPad Software Inc., CA) using twoway ANOVA followed by Bonferroni correction.

\section{RESULTS}

\section{Cytotoxic effects}

Cytotoxic effects of complex 1 and complex 2 were tested against breast cancer cell lines MCF-7, MDAMB-231 and 4T1, and Vero cells were used as non-tumorigenic cell line. Different concentrations were tested $(250 \mu \mathrm{M}, 137.5 \mu \mathrm{M}, 25 \mu \mathrm{M}, 13.75 \mu \mathrm{M}$ and $2.5 \mu \mathrm{M})$, and ibuprofen and diclofenac were used in the same concentrations in cell lines as a control.

Both complex 1 and complex 2 exhibited more than 60\% reduction in $4 \mathrm{~T} 1$ cell viability at the concentrations of 250 and $137.5 \mu \mathrm{M}$, when compared to controls (Figure 2A and 2E). Complex 1 also decreased viability at $25 \mu \mathrm{M}(22.88 \%$ reduction). Only complex 1 decreased cell viability at the concentrations of $250 \mu \mathrm{M}$ and $137.5 \mu \mathrm{M}$ in MCF-7 (34.35\% and 26.42\% reduction, respectively) (Figure 2B) and in MDAMB-231 (57.2\% and 22.88\% reduction, respectively) (Figure $2 \mathrm{C}$ ). Complex 2 showed no significant reduction in MCF-7 and MDA-MB-231, compared to ibuprofen (Figure 2F and 2G). Using non-tumorigenic cell lines (Vero), we observe that both compounds decreased viability at $250 \mu \mathrm{M}(29.96 \%$ for complex 1 and $29.97 \%$ for complex 2), and at 137,5 $\mu \mathrm{M}$, only complex 1 caused reduction (30.58\%), showing a cytotoxic and nonselective effect (Figure 2D and $2 \mathrm{H}$ ). 
A

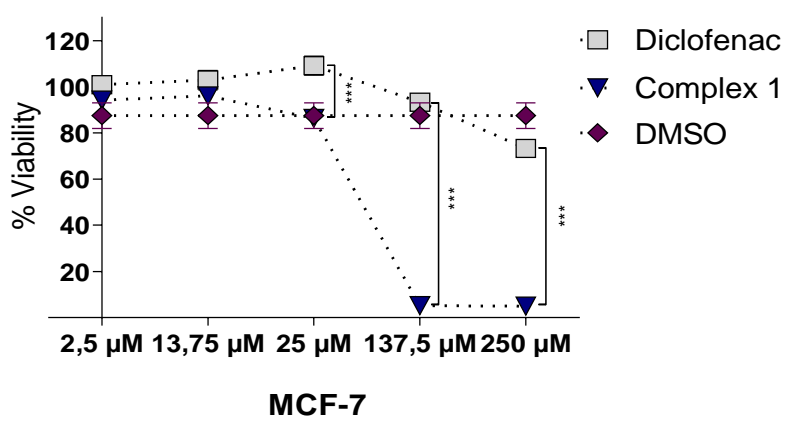

B

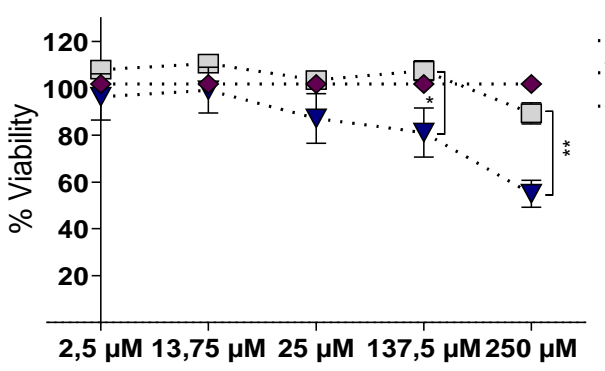

C

MDA-MB-231

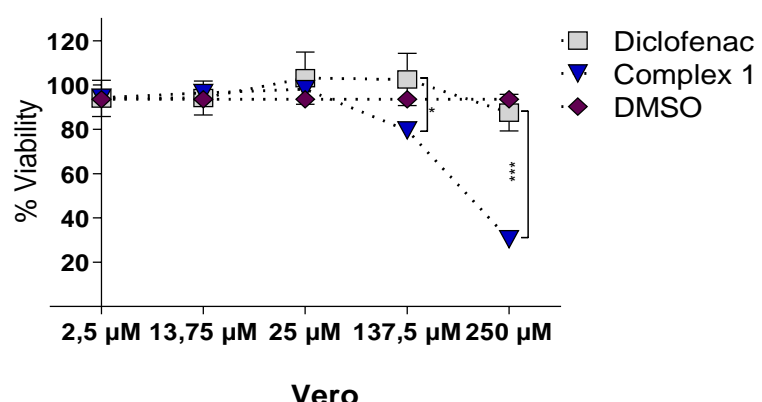

D

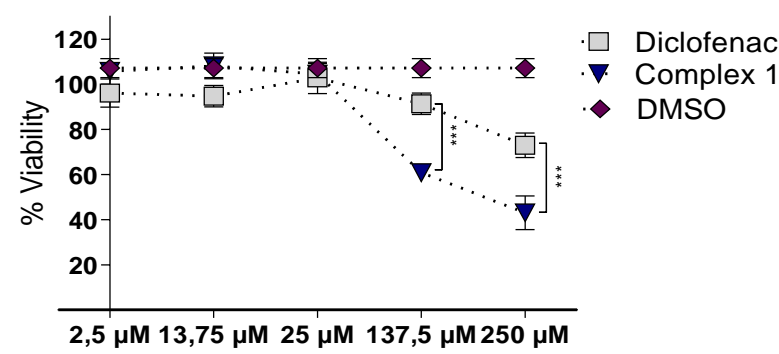

4T1

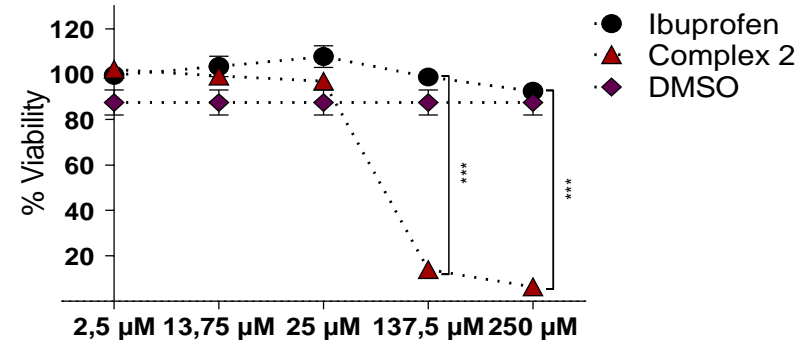

$\mathbf{F}$

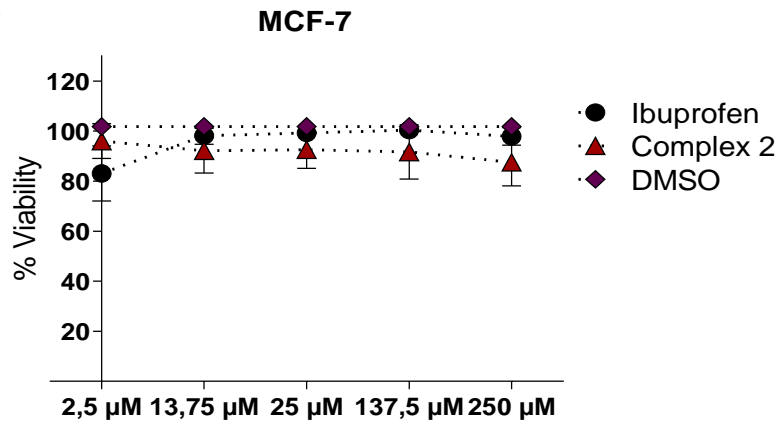

G

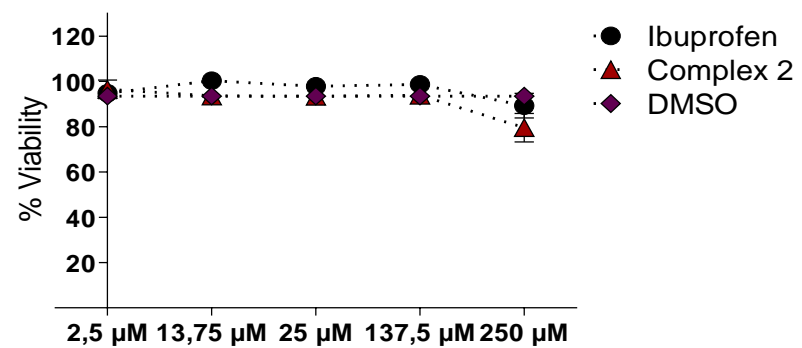

H

Vero

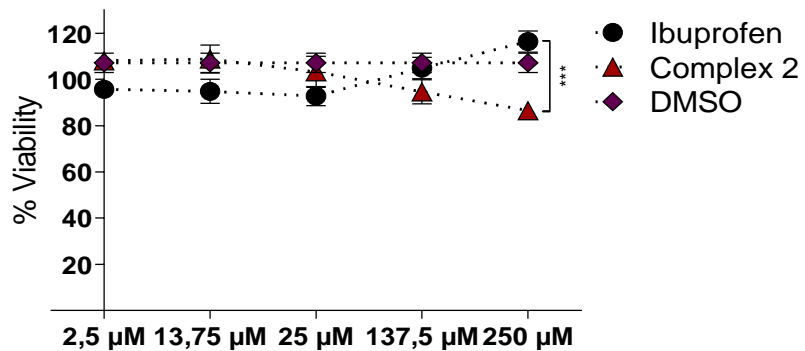

Figure 2. Cytotoxicity of complex 1, complex 2 and controls (ibuprofen and diclofenac). (A) Viability of $4 T 1$ cells treated with complex 1 and diclofenac. (B) Viability of MCF-7 cells treated with complex 1 and diclofenac. (C) Viability of MDAMB-231 cells treated with complex 1 and diclofenac. (D) Viability of Vero cells treated with complex 1 and diclofenac. (E) Viability of 4T1 cells treated with complex 2 and ibuprofen. (F) Viability of MCF-7 cells treated with complex 2 and ibuprofen. (G) Viability of MDA-MB-231 cells treated with complex 2 and ibuprofen. $(H)$ Viability of Vero cells treated with complex 2 and ibuprofen. Cell viability was measured by MTT assay. Dose response curves represent viability $24 \mathrm{~h}$ after treatment with $2.5-250 \mu \mathrm{M}$ of each compound performed in triplicates. DMSO was used as a vehicle control. Values represent the mean and standard deviation of two independent experiments. * indicates $p$-values lower than $0.05,{ }^{* *}$ indicates $p$-values lower than 0.01 and ${ }^{* * *}$ indicates $p$-values lower than 0.001 .

\section{IC50 values}

The IC50 values (the concentration of a drug that is required for $50 \%$ inhibition in vitro) were calculated for each complex and controls (Table 1). We found that for all cell lines tested, complex 1 exhibited the lowest IC50 compared to controls and complex 2 in all cell lines, indicating that it had the greatest cytotoxic effects. 
Although complex 1 was effective at inhibiting tumor cell lines growth, it also inhibited Vero cells. Complex 2 presented lower IC50 value for 4T1 cells comparing to the other cell lines, so 4T1 was the cell line that was more affected by the compounds' activity. When controls were tested, diclofenac showed lower IC50 values than ibuprofen, because it is more cytotoxic.

Table 1. Cytotoxic activity (IC50 $\mu \mathrm{M}$ ) of compounds (complex 1 and complex 2) and controls (ibuprofen and diclofenac).

\begin{tabular}{lcccc}
\hline Cell line & Complex 1 & Complex 2 & Diclofenac & Ibuprofen \\
\hline 4T1 & 103,3 & 117,23 & 459,77 & 1252,08 \\
MDA-MB-231 & 202,56 & 838,98 & 1017,02 & 1737,15 \\
MCF-7 & 298,05 & 1770,56 & 1788,79 & 5061,17 \\
Vero & 251,32 & 787,14 & 729,92 & 972,15 \\
\hline
\end{tabular}

\section{Selectivity index}

Selectivity index (SI) (Table 2) is a ratio that measures the window between cytotoxic and antitumoral activity. We used the IC50 found in Vero cells and divided by IC50 of tumoral cells. For both 4T1 and MDAMB-231 cells, complex 1 was selective, as its SI was $>1$. Complex 2 presented selective effects only on $4 \mathrm{~T} 1$ cells. For MCF-7, neither the compounds nor the controls exhibited a $\mathrm{SI}>1$, showing that they are all not selective for this cell line. Diclofenac had a $\mathrm{SI}>1$ for $4 \mathrm{~T} 1$, and ibuprofen showed a $\mathrm{SI}<1$ for all cell lines tested, meaning that it is not selective.

Table 2. Selectivity index (SI) of compounds (complex 1 and complex 2) and controls (ibuprofen and diclofenac).

$\begin{array}{lllll}\text { Cell line } & \text { Complex } 1 & \text { Complex } 2 & \text { Diclofenac } & \text { Ibuprofen }\end{array}$

\begin{tabular}{lllll}
\hline 4T1 & 2,43 & 6,71 & 1,58 & 0,77 \\
MDA-MB-231 & 1,24 & 0,93 & 0,71 & 0,55 \\
MCF-7 & 0,84 & 0,44 & 0,40 & 0,19 \\
\hline
\end{tabular}

Since the compounds exhibited the greatest effects on tumor cell growth of $4 \mathrm{~T} 1$ cell line, we sought to examine the effect of the complexes at viability through different time points (6h, $12 \mathrm{~h}, 24 \mathrm{~h}$ and $48 \mathrm{~h}$ ) in order to observe when the cytotoxic effect starts (Figure 3). Both complex $\mathbf{1}$ and $\mathbf{2}$ had a time-dependent effect on cell viability, after $6 \mathrm{~h}$ of the treatment we found a significant reduction on viability comparing to controls (Figure $3 \mathrm{~A}$ and $3 \mathrm{~B}$ ). Diclofenac decreased around $30 \%$ cell viability after $48 \mathrm{~h}$, and in contrast to ibuprofen that did not affect cell viability. 


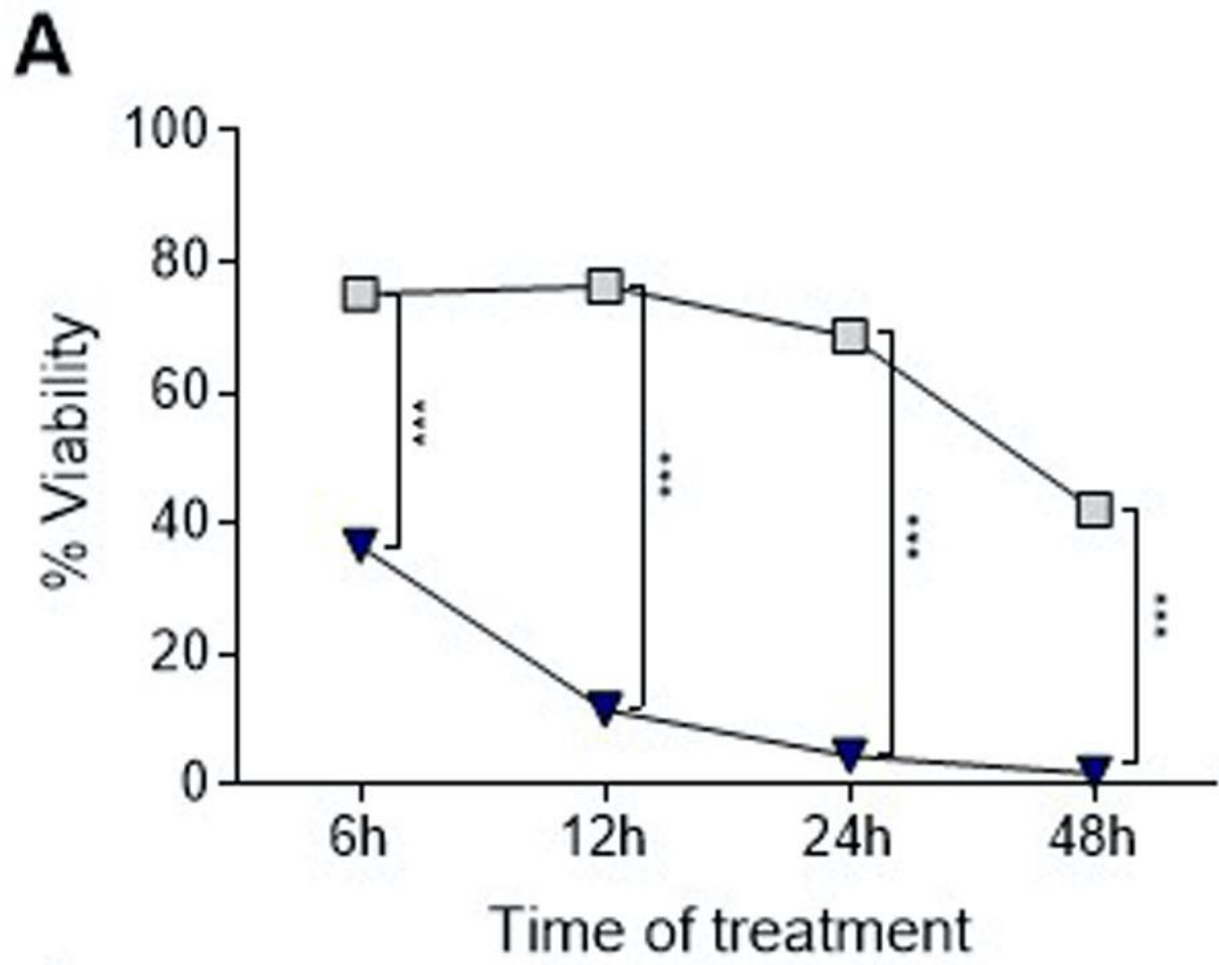

B

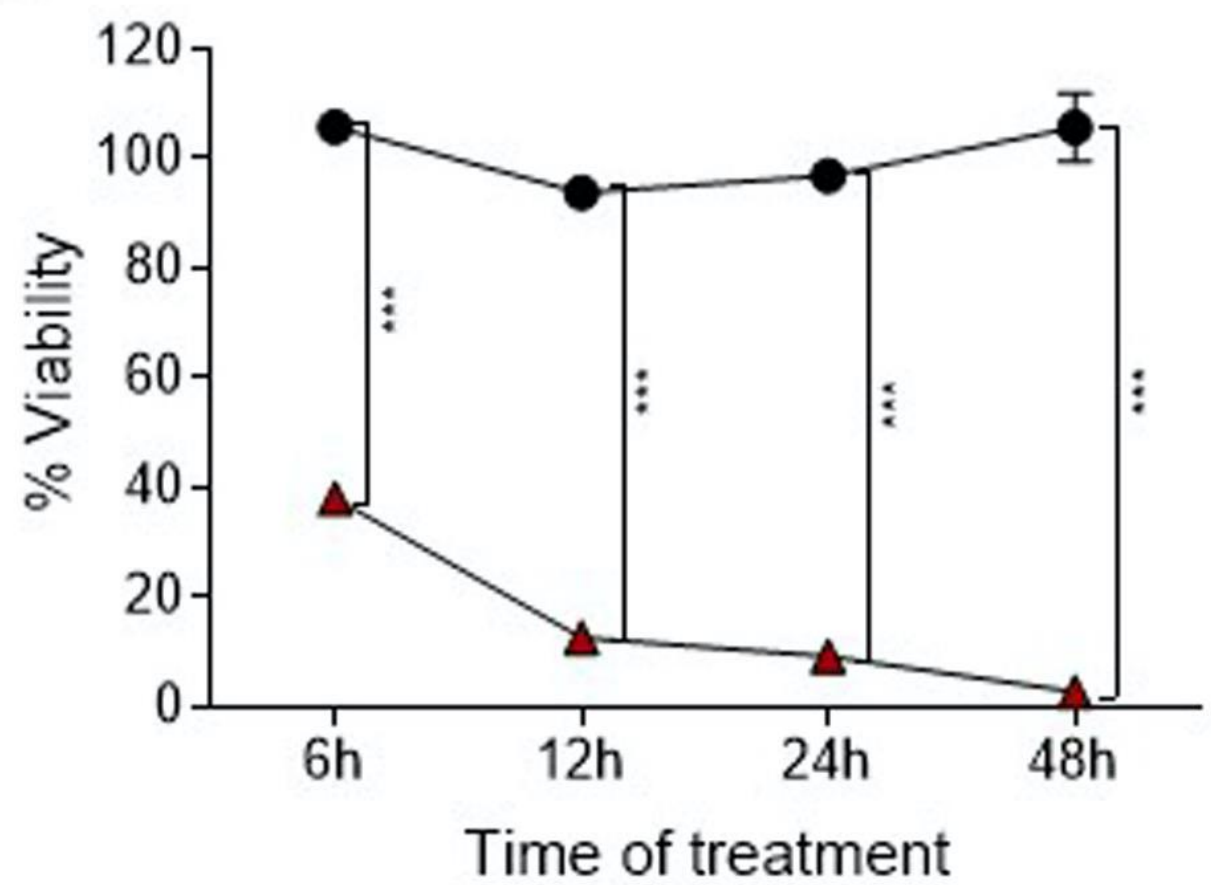

- Ibuprofen ^^ Complex 2

Figure 3. Cytotoxicity of $4 \mathrm{~T} 1$ cells after $6 \mathrm{~h}, 12 \mathrm{~h}, 24 \mathrm{~h}$ and $48 \mathrm{~h}$ of treatment with compounds and controls. (A) $4 \mathrm{~T} 1 \mathrm{cells}$ treated with complex 1 and diclofenac. (B) Cells treated with complex 2 and ibuprofen. Cell viability was measured by MTT assay. Cells were treated with $250 \mu \mathrm{M}$ of compounds and controls. Values represent the mean and standard deviation of three replicates of one experiment. * indicates $p$-values lower than $0.05,{ }^{* *}$ indicates $p$-values lower than 0.01 and $^{* * *}$ indicates $p$-values lower than 0.001 .

\section{DISCUSSION}

Breast cancer is one of the leading causes of death in the developed world, especially among women, implying in high costs treatments, which sometimes causes major side effects. For this reason, several studies have been performed to better understand the mechanisms of compounds candidates to be used as treatment of cancer. 
Our study and others showed that organometallic compounds derived from ibuprofen and diclofenac presented inhibition of tumor cell growth in vitro $(38,39,41)$. We found that complex $\mathbf{1}$, derived from diclofenac, and complex 2, derived from ibuprofen, decreased cell viability in breast cancer cell lines when compared to controls, especially after $48 \mathrm{~h}$ of treatment, which may be associated with their high stability (42). Since the addition of metals to an organic molecule can augment its pharmacological properties, possibly the coordination to $\mathrm{Zn}^{+}$caused this effect on these complexes. When compounds were tested against $4 \mathrm{~T} 1$ cells in different time points, we observed that cytotoxicity effects started at $6 \mathrm{~h}$ and increased over time, suggesting that the compounds might affect cell death. Furthermore, the presence of nicotinamide increases the solubility of compounds (42), which may be related to the cytotoxicity of both complexes $(38,47,48)$. It was previously demonstrated that the complexed form of the Zn II NSAIDs and the Nic binder produces molecules of low toxicity, no DNA cleavage activity (instead of its ability to interact with the molecule) and low chemical lability in polar solvent (42).

The mechanism used by the compounds to reduce cell viability remains unknown, however we hypothesize that it is related to COX inhibition, as other groups found with other NSAIDs-derived compounds $(30,49)$. Both ibuprofen and diclofenac are non-selective COX inhibitors, meaning they inhibit both COX-1 and 2, although diclofenac has a higher selectivity for COX-2 $(50,51)$. MDA-MB-231 and 4T1 were previously shown to have high expression of COX-2 and MCF-7 showed low expression of COX-2 (52). Thus, we hypothesize that complex 1 had more cytotoxic effect on MDA-MB-231 and 4T1 cells because since it is derived from diclofenac, it preferably inhibits COX-2. Specially for breast cancer, COX-2 was sufficient to promote tumorigenesis in transgenic mice (53) and was also related to higher histological grade, tumors with larger sizes, high Ki-67 and p53 expression, negative hormone receptor status, HER-2 amplification and presence of axillary lymph node metastases (18).

Both compounds did not show greater cytotoxic effects in MCF-7 cells - which may be due to low COX2 expression - and presented more cytotoxic effects against 4T1 cell lines. Interestingly the complex 1 presented a cytotoxic effect on MDA-MB-231. The distinct effects of compounds on BC cell lines are probably due to different phenotype and origin of the cells, as 4T1 cells are originated from mice, and MCF-7 and MDA-MB-231 from human invasive breast ductal carcinoma. Additionally, molecular subtypes of each cell are individual, as MCF-7 is classified as luminal (less aggressive, better prognosis) and MDA-MB-231 as claudin-low (more aggressive, worse prognosis) $(44,54)$. Other study presented alternative pathways that show how NSAIDs, including ibuprofen and diclofenac, can act on MDA-MB-231 cell lines, through inhibiting the sirtuin 1 (SIRT1) deacetylase activity, increasing acetylation and activity of the tumor suppressor p53 and the expression of the antiproliferative gene p21 (55). Moreover, studies with diclofenac showed COXindependent mechanisms, such as modulation of MYC expression and glucose metabolism, resulting in impaired carcinoma cell line proliferation in murine melanoma cell line B16F10 (56).

In summary, our results demonstrated that complexes $\mathbf{1}$ and $\mathbf{2}$ are more effective than the NSAIDs ibuprofen and diclofenac in reducing cellular growth in three different breast cancer cell lines, highlighting the potential antitumoral activity of Zinc-NSAIDs and Nic complexes. In this context, future studies should be conducted to better understand the mechanism by which the synthesized compounds, complex 1 and complex 2, act on cell viability.

Funding: This research was funded by FAPERGS 16/2551-0000523-0 and CAPES financial code 1.

Acknowledgments: We thank Dr. Jarbas Rodrigues de Oliveira and Dr. Cristiano Valim Bizarro for the contribution on the project.

Conflicts of Interest: The authors declare no conflict of interest. The funders had no role in the design of the study; in the collection, analyses, or interpretation of data; in the writing of the manuscript, or in the decision to publish the results.

\section{REFERENCES}

1. Christopher PW, Bernard WS, Elisabeth W. World Cancer Report 2020. Lyon: WHO International agency for Research on cancer; 2020 p. 613

2. Bray F, Ferlay J, Soerjomataram I, Siegel RL, Torre LA, Jemal A. Global cancer statistics 2018: GLOBOCAN estimates of incidence and mortality worldwide for 36 cancers in 185 countries. CA: A Cancer J. for Clin. 2018;68(6):394-424.

3. Boodram JN, Mcgregor IJ, Bruno PM, Cressey PB, Hemann MT, Suntharalingam K. Breast Cancer Stem Cell Potent Copper(II)-Non-Steroidal Anti-Inflammatory Drug Complexes. Angew. Chem. - Int. Ed. 2016;55(8):2845-50.

4. Feng J, Du X, Liu H, Sui X, Zhang $\mathrm{C}$, Tang $\mathrm{Y}$, et al. Manganese-mefenamic acid complexes exhibit high lipoxygenase inhibitory activity. Dalton Transactions. 2014;43(28):10930-9. 
5. Ricciotti E, Fitzgerald GA. Prostaglandins and inflammation. Arterioscler, Thromb, and Vasc Biol. 2011;31(5):9861000.

6. Kobayashi K, Omori K, Murata T. Role of prostaglandins in tumor microenvironment. Cancer Metastasis Rev. 2018;37(2-3):347-54.

7. Smith WL, DeWitt DL, Garavito RM. Cyclooxygenases: Structural, Cellular, and Molecular Biology. Annu. Rev. of Biochem. 2000 Jun;69:145-82.

8. Sharpe CR, Collet J-P, McNutt M, Belzile E, Boivin J-F, Hanley JA. Nested case-control study of the effects of nonsteroidal anti-inflammatory drugs on breast cancer risk and stage. Br J Cancer. 2000 Jul;83(1). 112-20.

9. Moris D, Kontos M, Spartalis E, Fentiman IS. The Role of NSAIDs in Breast Cancer Prevention and Relapse: Current Evidence and Future Perspectives. Breast Care. 2016;11(5). 339-344.

10. Bittoni MA, Carbone DP, Harris RE. Ibuprofen and fatal lung cancer: A brief report of the prospective results from the Third National Health and Nutrition Examination Survey (NHANES III). Mol. and Clin. Oncol. [Internet]. 2017;6(6):917-20. Available from: https://www.spandidos-publications.com/

11. Muscat JE, Chen S-Q, Richie JP, Altorki NK, Citron M, Olson S, et al. Risk of lung carcinoma among users of nonsteroidal antiinflammatory drugs. Cancer. 2003 Apr 1;97(7). 1732-6.

12. Doat $S$, Cénée $S$, Trétarre $B$, Rebillard X, Lamy $P$, Bringer J, et al. Nonsteroidal anti-inflammatory drugs (NSAIDs) and prostate cancer risk: results from the EPICAP study. Cancer Med. 2017;6(10):2461-70.

13. Daugherty SE, Pfeiffer RM, Sigurdson AJ, Hayes RB, Leitzmann M, Schatzkin A, et al. Nonsteroidal antiinflammatory drugs and bladder cancer: A pooled analysis. Am. J. of Epidemiol. 2011;173(7):721-30.

14. Wernli KJ, Newcomb PA, Hampton JM, Trentham-Dietz A, Egan KM. Inverse association of NSAID use and ovarian cancer in relation to oral contraceptive use and parity. Br J Cancer. 2008;98(11):1781-3.

15. Baandrup L, Faber MT, Christensen J, Jensen A, Andersen KK, Friis S, et al. Nonsteroidal anti-inflammatory drugs and risk of ovarian cancer: Systematic review and meta-analysis of observational studies. Acta Obstet. Gynecol. Scand. 2013;92:245-55.

16. Corley D, Kerlikowske K, Verma R, Buffler P. Protective association of aspirin/NSAIDs and esophageal cancer: A systematic review and meta-analysis. Gastroenterology. 2003;124(1):47-56.

17. Huang $\mathrm{X}$, Chen $\mathrm{Y}, \mathrm{Wu} \mathrm{J}$, Zhang $\mathrm{X}$, Wu $\mathrm{C}$, Zhang $\mathrm{C}$, et al. Aspirin and non-steroidal anti-inflammatory drugs use reduce gastric cancer risk: A dose-response meta-analysis. Oncotarget. 2017;8(3):4781-95.

18. Dell'Omo G, Crescenti D, Vantaggiato C, Parravicini C, Borroni AP, Rizzi N, et al. Inhibition of SIRT1 deacetylase and p53 activation uncouples the anti-inflammatory and chemopreventive actions of NSAIDs. Br J Cancer. 2019;120:537-46.

19. Grivennikov SI, Karin M. Inflammation and oncogenesis: a vicious connection. Vol. 20, Curr. Opin. Genet. and Dev. 2010. p. 65-71.

20. Grivennikov SI, Greten FR, Karin M. Immunity, Inflammation, and Cancer. Cell. 2010.19, 140(6)883-99.

21. Bartsch H, Nair J. Chronic inflammation and oxidative stress in the genesis and perpetuation of cancer: Role of lipid peroxidation, DNA damage, and repair. Langenbeck's Arch. Surg. 2006;391:499-510.

22. Hashemi Goradel N, Najafi M, Salehi E, Farhood B, Mortezaee K. Cyclooxygenase-2 in cancer: A review. J. Cell. Physiol. 2019.234:5683-99.

23. Ohtsuka J, Oshima H, Ezawa I, Abe R, Oshima M, Ohki R. Functional loss of p53 cooperates with the in vivo microenvironment to promote malignant progression of gastric cancers. Sci Rep. 2018;8(1):2291.

24. Tuncer S, Banerjee S. Eicosanoid pathway in colorectal cancer: Recent updates. World J. of Gastroenterol. 2015;7(21):11746-66.

25. Echizen K, Hirose O, Maeda $\mathrm{Y}$, Oshima M. Inflammation in gastric cancer: Interplay of the COX-2/prostaglandin E 2 and Toll-like receptor/MyD88 pathways. Cancer Sci. 2016 Apr 18;107(4). 391-7.

26. Howe LR. Inflammation and breast cancer. Cyclooxygenase/prostaglandin signaling and breast cancer. Breast Cancer Res. 2007;9(4):210.

27. Dong XF, Liu TQ, Zhi XT, Zou J, Zhong JT, Li T, et al. COX-2/PGE2 axis regulates HIF2a activity to promote hepatocellular carcinoma hypoxic response and reduce the sensitivity of sorafenib treatment. Clin. Cancer Res. 2018;24(13):3204-16.

28. Esbona K, Yi Y, Saha S, Yu M, van Doorn RR, Conklin MW, et al. The Presence of Cyclooxygenase 2, TumorAssociated Macrophages, and Collagen Alignment as Prognostic Markers for Invasive Breast Carcinoma Patients. Am. J. of Pathol. 2018;188(3):559-73.

29. Greenhough A, Smartt HJM, Moore AE, Roberts HR, Williams AC, Paraskeva C, et al. The COX-2/PGE2 pathway: key roles in the hallmarks of cancer and adaptation to the tumour microenvironment. Carcinogenesis. 2009 Jan 9;30(3): $377-86$ 
30. Bacchi S, Palumbo P, Sponta A, Coppolino MF. Clinical Pharmacology of Non-Steroidal Anti-Inflammatory Drugs : A Review. Antiinflamm Antiallergy Agents Med Chem. 2012;11(1):52-64.

31. Smith GS, Therrien B. Targeted and multifunctional arene ruthenium chemotherapeutics. Dalton Trans. 2011;40:10793-800.

32. Zaki M, Hairat S, Aazam ES. Scope of organometallic compounds based on transition metal-arene systems as anticancer agents: Starting from the classical paradigm to targeting multiple strategies. RSC Advances. 2019;9:3239-78.

33. Szczepaniak A, Fichna J. Organometallic compounds and metal complexes in current and future treatments of inflammatory bowel disease and colorectal cancer-a critical review. Biomolecules. 2019;22(9):398.

34. Ronconi L, Sadler PJ. Using coordination chemistry to design new medicines. Coord. Chem. Rev. 2007; 251:163348.

35. Gianferrara T, Bratsos I, Alessio E. A categorization of metal anticancer compounds based on their mode of action. Dalton Trans. 2009;(37): 7588-98.

36. Allgeier AM, Mirkin CA. Ligand Design for Electrochemically Controlling Stoichiometric and Catalytic Reactivity of Transition Metals. Angew. Chem. Int. Ed. 1998 Apr 20;37(7):894-908.

37. Gasser G, Metzler-Nolte N. The potential of organometallic complexes in medicinal chemistry. Curr. Opin. Chem. Biol. 2012 Apr;16(1-2):84-91.

38. Mandal P, Kundu BK, Vyas K, Sabu V, Helen A, Dhankhar SS, et al. Ruthenium (II) arene NSAID complexes: Inhibition of cyclooxygenase and antiproliferative activity against cancer cell lines. Dalton Trans. 2018;47(2):51727.

39. Alves Rico SR, Abbasi AZ, Ribeiro G, Ahmed T, Wu XY, de Oliveira Silva D. Diruthenium(II,III) metallodrugs of ibuprofen and naproxen encapsulated in intravenously injectable polymer-lipid nanoparticles exhibit enhanced activity against breast and prostate cancer cells. Nanoscale. 2017;9(30):10701-14.

40. Hanif-Ur-Rehman, Freitas TE, Gomes RN, Colquhoun A, de Oliveira Silva D. Axially-modified paddlewheel diruthenium(II,III)-ibuprofenato metallodrugs and the influence of the structural modification on U87MG and A172 human glioma cell proliferation, apoptosis, mitosis and migration. J. Inorg. Biochem. [Internet]. 2016;165:181-91. Available from: http://dx.doi.org/10.1016/j.jinorgbio.2016.10.003

41. Intini FP, Zajac J, Novohradsky V, Saltarella T, Pacifico C, Brabec V, et al. Novel Antitumor Platinum (II) Conjugates Containing the Nonsteroidal Anti-inflammatory Agent Diclofenac: Synthesis and Dual Mechanisms of Antiproliferative Effects. Inorg. Chem. 2017;56(3):1483-97.

42. Dos Santos PR, Pich CT, Back D, Smiderle F, Dumas F, Moura S. Synthesis, chemical characterization and DNA interaction study of new diclofenac and ibuprofen zinc (II)-nicotinamide ternary complexes as cyclooxygenase inhibitor prototypes. J. Inorg. Biochem. [Internet]. 2020;206(February):111046. Available from: https://doi.org/10.1016/j.jinorgbio.2020.111046

43. Pulaski BA, Ostrand-Rosenberg S. Mouse 4T1 Breast Tumor Model. Curr. Protoc. in Immunol. 2000 Oct;39(1).

44. Holliday DL, Speirs V. Choosing the right cell line for breast cancer research. Breast Cancer Research. 2011 Aug 12;13(4). 215.

45. Abu Ali H, Jabali B. Synthesis, characterization and biological activity of novel complexes of zinc(II) diclofenac with nitrogen based ligands. Polyhedron. 2016;107:97-106.

46. Abu Ali H, Omar SN, Darawsheh MD, Fares H. Synthesis, characterization and antimicrobial activity of zinc(II) ibuprofen complexes with nitrogen-based ligands. J. Coord. Chem. 2016;69(6):1110-22.

47. Quispe M A, Zavala C D, Rojas C J, Posso R M, Vaisberg W A. Efecto citotóxico selectivo in vitro de muricin $H$ (acetogenina de Annona muricata) en cultivos celulares de cáncer de pulmón. Rev peru med exp salud publica. 2006;23(4):256-69.

48. Benadiba M, dos Santos RRP, Silva D de O, Colquhoun A. Inhibition of C6 rat glioma proliferation by [Ru2Cl(Ibp)4] depends on changes in $\mathrm{p} 21, \mathrm{p} 27, \mathrm{Bax} / \mathrm{Bcl} 2$ ratio and mitochondrial membrane potential. J. Inorg. Biochem. [Internet]. 2010;104(9):928-35. Available from: http://dx.doi.org/10.1016/j.jinorgbio.2010.04.011

49. Tabrizi L, Olasunkanmi LO, Fadare OA. Experimental and theoretical investigations of cyclometalated ruthenium(ii) complex containing CCC-pincer and anti-inflammatory drugs as ligands: synthesis, characterization, inhibition of cyclooxygenase and in vitro cytotoxicity activities in various can. Dalton Trans. 2019;48:728-40.

50. Neil JR, Johnson KM, Nemenoff RA, Schiemann WP. Cox-2 inactivates Smad signaling and enhances EMT stimulated by TGF- $\beta$ through a PGE2-dependent mechanisms. Carcinogenesis. 2008;29(11):2227-35.

51. Grosser T. Biological basis for the cardiovascular consequences of COX-2 inhibition: therapeutic challenges and opportunities. J. Clin. Investig. 2005 Dec 8;116(1):4-15.

52. Majumder M, Dunn L, Liu L, Hasan A, Vincent K, Brackstone M, et al. COX-2 induces oncogenic micro RNA miR655 in human breast cancer. Sci Rep. 2018;8(1):327. 
53. Liu CH, Chang SH, Narko K, Trifan OC, Wu MT, Smith E, et al. Overexpression of Cyclooxygenase-2 is Sufficient to Induce Tumorigenesis in Transgenic Mice. J. Biol. Chem. 2001;276(21):18563-9.

54. Ristimäki A, Sivula A, Lundin J, Lundin M, Salminen T, Haglund C, et al. Prognostic significance of elevated cyclooxygenase-2 expression in breast cancer. Cancer Res. 2002;62(3):632-5.

55. Dai X, Cheng H, Bai Z, Li J. Breast cancer cell line classification and Its relevance with breast tumor subtyping. J. Cancer. 2017;8:3131-41.

56. Gottfried E, Lang SA, Renner K, Bosserhoff A, Gronwald W, Rehli M, et al. New Aspects of an Old Drug - Diclofenac Targets. Plos One, 2013;(7):e66987.

(C) 2021 by the authors. Submitted for possible open access publication under the terms and conditions of the Creative Commons Attribution (CC BY NC) license (https://creativecommons.org/licenses/by-nc/4.0/). 